\title{
PENINGKATAN KINERJA MENGAJAR GURU TK AL ISRO KOTA JAMBI MELALUI SUPERVISI AKADEMIK DENGAN TEKNIK OBSERVASI KELAS
}

\author{
YUSLIARTI \\ TK Al Isro’ Kota Jambi \\ Email: yusliartii@gmail.com
}

\begin{abstract}
ABSTRAK
Penelitian bertujuan untuk mengetahui peningkatan aktivitas dan kinerja mengajar guru TK Al Isro' kota Jambi selama dilakukan supervisi akademik dengan teknik observasi kelas. Hasil dari penelitian ini, setelah dilakukan Supervisi Akademik dengan dua siklus mengalami peningkatan, pada siklus I dengan skor 63,25 dengan Kategori C meningkat 6,25\%. Pada siklus II meningkat 22,50\% dengan Skor 79,50, dengan kategori B, ketuntasan kasikal 100\%. Kinerja mengajar pada aspek melaksanakan pembelajaran kondisi pra siklus dengan skor 61,05, kategori $C$, kondisi siklus I meningkat 0,30\% dengan skor 61,35, kategori C, setelah siklus II Meningkat 15,31\% dengan skor 76,36, dengan kategori B, ketuntasan klasikal 100\%. Sedangkan Kinerja mengajar pada aspek mengevaluasi hasil belajar siswa kondisi pra siklus dengan skor 56,93, kategori $C$, setelah siklus I meningkat 0,03\% dengan skor 56,95 kategori C. Setelah siklus II meningkat 18,63\% dengan skor 75,56, ketuntasan klasikal 100\% dengan kategori B.
\end{abstract}

Kata kunci: Kinerja Mengajar, Supervisi akademik, Observasi kelas

\section{A. PENDAHULUAN}

\section{Latar Belakang Masalah}

Guru dalam melaksanakan tugas selalu menunjukkan kualitas profesionalismenya dengan berkeinginan untuk selalu menampilkan perilaku yang mendekati standart yang ideal, meningkatkan dan memelihara citra profesi. Ada keinginan untuk selalu mengejar kesempatan pengembangan profesional yang dapat meningkatkan dan memperbaiki kualitas pengetahuan dan keterampilan, mengejar kualitas dan cita-cita profesi, dan memiliki kebanggaan terhadap profesinya.

Pembelajaran dapat diartikan sebagai segala usaha atau proses kegitan belajar mengajar yang juga berperan dalam menentukan keberhasilan belajar siswa. Dari proses pembelajaran itu akan terjadi sebuah timbal balik antara guru 
dan siswa untuk menuju tujuan yang lebih baik. Oleh karena itu pembelajaran di TK berpedoman dan berprinsip pada belajar sambil bermain dan bermain seraya belajar, dengan menggunakan pedekatan tematik, dan berpusat pada anak.

Supervisi akademik adalah serangkaian kegiatan membantu guru mengembangkan kemampuan dalam mengelola proses pembelajaran. Supervisi akademik tidak terlepas dari penilaian kinerja mengelola pembelajaran. Sergiovani menegaskan bahwa refleksi praktis penilaian kinerja mengajar guru dalam supervisi akademik adalah melihat kondisi nyata kinerja mengajar untuk menjawab pertanyaan tentang apa yang terjadi di dalam kelas, apa yang dilakukan guru dan peserta didik, aktifitas apa yang bermakna bagi guru dan peserta didik, dari jawaban pertanyaan tersebut akan diperoleh informasi guru dalam mengelola pembelajaran. Artinya supervisi akademik bukan menilai unjuk kerja guru dalam mengelola proses pembelajaran, melainkan membantu guru dalam mengembangkan kemampuan professionalismenya.

Berdasarkan hasil observasi penulis di lapangan dapat diketahui bahwa kemampuan atau prestasi kinerja mengajar guru-guru di TK Al Isro' masih dengan kategori sedang. Kesenjangan antara tuntutan masyarakat dengan hasil supervisi akademik tentang pelaksanaan pembelajaran di TK menjadi perhatian peneliti untuk mengadakan penelitian tindakan sekolah di TK Al Isro' Kota Jambi dengan judul: Peningkatan Kinerja Mengajar Guru Tk Al Isro Kota Jambi Melalui Supervisi Akademik Dengan Teknik Observasi Kelas”.

\section{Rumusan Masalah}

Berdasarkan uraian latar belakang masalah, maka rumusan masalah sebagai berikut:

a. Melalui Supervisi akademik dengan teknik observasi kelas, adakah peningkatan kinerja mengajar guru Taman Kanak-kanak A1 Isro’ kota Jambi?

b. Bagaimanakah aktivitas dan semangat kinerja mengajar guru Taman Kanakkanak TK Al Isro’ Kota Jambi? 


\section{Tujuan Penelitian}

Tujuan yang ingin dicapai dalam penelitian tindakan sekolah, yaitu:

a. Untuk mengetahui peningkatan kinerja mengajar guru Taman Kanak-Kanak Al Isro’ Kota Jambi;

b. Untuk mengetahui aktivitas dan semangat kinerja mengajar guru Taman Kanak-kanak Al Isro’ Kota Jambi.

\section{Manfaat Penelitian}

Penelitian Tindakan Sekolah (PTS) ini diharapkan dapat memberikan manfaat bagi:

\section{- Bagi Siswa}

Dengan adanya penelitian tindakan sekolah (PTS) ini diharapkan dapat meningkatkan kemampuan siswa siswa dalam belajar.

\section{- Bagi Guru}

Penelitian ini diharapkan dapat meningkatkan kinerja guru dalam mengajar, baik dalam pemilihan media maupun dalam penentuan metode mengajar.

\section{- Bagi Sekolah}

Dapat dijadikan sumbangan pemikiran dalam mewujudkan sekolah yang dapat mendorong keberhasilan dan peningkatan mutu pembelajaran.

\section{B. KAJIAN PUSTAKA}

\section{Pengertian Kinerja Guru}

Istilah kinerja berasal dari kata job performance atau actual performance (prestasi kerja atau prestasi sesungguhnya yang dicapai oleh seseorang). Kinerja adalah hasil kerja secara kualitas dan kuantitas yang dicapai oleh seorang pegawai dalam melaksanakan tugasnya sesuai dengan tanggung jawab yang diberikan kepadanya. ${ }^{1}$ Kinerja merupakan suatu kegiatan yang dilakukan untuk

\footnotetext{
${ }^{1}$ Anwar Prabu Mangkunegara, Manajemen Sumber Daya Manusia Perusahaan. (Bandung: PT. Remaja Rosdakarya, 2007), hal. 67
} 
melaksanakan, menyelesaikan tugas dan tanggung jawab sesuai dengan harapan dan tujuan yang telah ditetapkan. ${ }^{2}$

Bernardin dan Russel berpendapat "performance is defined as the record of outcome produced on a specified job function or activity during time period"“ Pernyataan di atas dapat dipahami bahwa kinerja atau prestasi adalah catatan tentang hasil- hasil yang diperoleh dari fungsifungsi pekerjaan tertentu atau kegiatan selama kurun waktu tertentu. Smith dalam Mulyasa menyatakan bahwa Kinerja adalah: output drive from processes, human or otherwise. Prestasi atau kinerja merupakan hasil atau keluaran dari suatu proses. Selanjutnya Mulyasa mengatakan bahwa kinerja atau performance dapat diartikan sebagai prestasi kerja, pelaksanaan kerja, pencapaian kerja, hasil hasil kerja.

Peraturan Menteri Pendidikan Nasional (Permendiknas) No. 41 tahun 2007, memberikan pengertian kinerja guru adalah prestasi mengajar yang dihasilkan dari aktivitas yang dilakukan oleh guru dalam tugas pokok dan fungsinya secara realisasi konkrit merupakan konsekuensi logis sebagai tenaga profesional bidang pendidikan. ${ }^{3}$

Undang- Undang Nomor 14 tahun 2005 telah memberikan gambaran bahwa kinerja guru adalah melaksanakan tugas utama dan menunaikan beban kerja, serta mewujudkan kompetensi dalam mengemban amanah pendidikan yang ada di pundaknya. ${ }^{4}$

Berdasarkan definisi kinerja sebagaimana telah diuraikan di atas, dapat disimpulkan bahwa kinerja guru merupakan kemampuan yang ditunjukkan oleh guru dalam melaksanakan tugas atau pekerjaannya. Kinerja dikatakan baik dan memuaskan apabila tujuan yang dicapai sesuai dengan standar yang telah ditetapkan. Kinerja guru mempunyai spesifikasi tertentu. Kinerja guru dapat dilihat dan diukur berdasarkan spesifikasi atau kriteria kompetensi yang harus dimiliki oleh setiap guru. Wujud perilaku yang dimaksud adalah kegiatan guru dalam proses pembelajaran yang meliputi perencanaan pembelajaran, pelaksanaan

\footnotetext{
${ }^{2}$ Supardi, Kinerja Guru, (Jakarta: Grafindo, 2014 ), hal. 45

${ }^{3}$ Permendiknas Nomor 41 Tahun 2007 tentang Standar Proses untuk Satuan Pendidikan Dasar dan Menengah. Departemen Pendidikan Nasional, Jakarta

${ }^{4}$ Undang-undang Republik Indonesia Nomor 14 Tahun 2005 tentang Guru dan Dosen.
} 
pembelajaran, evaluasi pembelajaran dan membina hubungan antar pribadi dengan siswanya.

\section{Kinerja Mengajar Guru}

Kinerja mengajar adalah prestasi yang diperlihatkan guru dalam menyampaikan materi pembelajaran (pengetahuan, keterampilan, dan sikap) kepada siswanya, karena guru tersebut mempunyai kemampuan merencanakan, melaksanakan, dan mengevaluasi proses belajar mengajar dalam suasana interaksi edukatif.

Kinerja mengajar merupakan penampilan kerja yang dilakukan oleh seorang guru dalam menjalankan tugas dan tanggung jawabnya dalam memberikan bimbingan belajar yang berisi pengetahuan dan keterampilan yang akan mengarah pada peningkatan prestasi peserta didik. Kinerja mengajar yang baik merupakan prasyarat bagi keberhasilan dan kesuksesan proses belajar mengajar. Dengan demikian untuk mencapai tujuan pendidikan yang telah ditetapkan, guru dituntut untuk senantiasa mampu tampil dengan baik.

Berdasarkan uraian di atas, dengan demikian tugas guru dalam mengajar perlu memiliki kemampuan merencanakan, melaksanakan, dan menilai hasil proses belajar mengajar. Hal tersebut merupakan sebagai perwujudan, penampilan atau kinerja mengajar guru dalam melaksanakan tugas profesinya sebagai pengajar. Kinerja mengajar guru adalah gambaran tentang hasil kerja seseorang guru berkaitan dengan tugas yang diembannya, dan didasarkan pada tanggung jawab profesional yang dimiliki, yaitu: (1) Kemampuan Merencanakan Program pengajaran, (2) kemampuan melaksanakan pembelajaran, (3) kemampuan mengevaluasi hasil belajar siswa.

\section{Supervisi Akademik}

Supervisi akademik pada dasarnya merupakan bagian dari kajian bidang supervisi, sehingga sebelum menuju pada devinisi supervisi akademik maka kita harus mengetahui apa itu supervsisi secara umum. Banyak sekali devinisi yang dikemukakan oleh para ahli mengenai apa itu supervisi, secara etimologi kata supervisi diambil dari bahasa Inggris yaitu Supervision yang artinya pengawasan dibidang pendidikan, sedangkan orang yang melakukan kegiatan supervsisi

VOLUME 1, NO. 2 Juli - Desember 2019 
disebut dengan supervisor. Sedangkan jika ditinjau dari segi morfologisnya kata supervisi bersal dari dua kata, yakni super berarti atas, lebih dan visi berarti lihat, tilik, awasi.

Beberapa tujuan kegiatan supervisi akademik menurut para ahli antara lain $^{5}$

a) Agar tercapainya tujuan pembelajaran yang direncanakan.

b) Diharapkan dapat meningkatkan kualitas akademik guru.

Menurut Sergiovanni, tujuan supervisi akademik yaitu:

1) Supervisi akademik diselenggarakan dengan maksud membantu guru mengembangkan kemampuan profesionalnya dalam memahami akademik, kehidupan kelas, mengembangkan keterampilan mengajarnya dan menggunakan kemampuannya melalui teknik-teknik tertentu.

2) Supervisi akademik diselenggarakan dengan maksud untuk memonitor kegiaan belajar mengajar di sekolah. Kegiatan monitor bisa dilakukan dengan melakukan kunjungan kepala sekolah ke kelas-kelas disaat guru sedang mengajar, percakapan pribadi dengan guru, teman sejawatnya maupun dengan murit-muritnya.

3) Supervisi akademik diselenggarakan untuk mendorong guru menerapkan kemampuannya dalam melaksanakan tugas-tugas mengajarnya, mendorong guru mengembangkan kemampuannya sendiri, serta mendorong guru agar ia memiliki perhatian yang sungguh-sungguh (commitement) terhadap tugas dan tanggung jawabnya.

Prinsip-prinsip supervisi akademik modern yang harus direalisasikan pada setiap proses supervisi akademik di sekolah-sekolah sebagaimana pendapat Tahalele dan Indra Fachrudi adalah sebagai berikut:

a. Supervisi akademik harus mampu menciptakan hubungan kemanusiaan yang harmonis, bersifat terbuka, kesetiakawanan, dan informal. Hubungan demikian ini bukan saja antara supervisor dengan guru, melainkan juga antara supervisor dengan pihak lain yang terkait dengan program supervisi akademik.

\footnotetext{
${ }^{5}$ Asf. Jasmani, Op. Cit., h. 35.
} 
b. Supervisi akademik harus dilakukan secara berkesinambungan. Supervisi akademik bukan tugas bersifat sambilan yang hanya dilakukan sewaktu-waktu jika ada kesempatan. Apabila guru telah berhasil mengembangkan dirinya tidaklah berarti selesailah tugas supervisor, melainkan harus tetap dibina secara berkesinambungan. Hal ini logis, mengingat problema proses pembelajaran selalu muncul dan berkembang.

c. Supervisi akademik harus demokratis. Supervisor tidak boleh mendominasi pelaksanaan supervisi akademiknya. Titik tekan supervisi akademik yang demokratis, aktif dan kooperatif. Supervisor harus melibatkan secara aktif guru yang dibinanya. Tanggung jawab perbaikan program akademik bukan hanya pada supervisor melainkan juga pada guru. Karena itu, program supervisi akademik sebaiknya direncanakan, dikembangkan dan dilaksanakan bersama secara kooperatif dengan guru, kepala sekolah, dan pihak lain yang terkait di bawah koordinasi supervisor.

Adapun ruang lingkup dari kegiatan supervisi akademik yang harus diketahui oleh para supervisor agar terarah dan tidak salah objek dalam pengkajiannya antara lain meliputi: ${ }^{6}$

a. Pelaksanaan kurikulum yang berlaku.

b. Perencanaan, pelaksanaan dan penilaian proses pembelajaran oleh guru.

c. Pencapaian Standar kompetensi lulusan (SKL), Standar proses, Standar isi, dan peraturan pelaksanaannya.

d. Peningkatan mutu pembelajaran melalui pengembangan model kegiatan pembelajaran, peran serta peserta didik dalam proses pembelajaran secara aktif, kreatif, demokratis, mendidik, memotivasi, mendorong kreatifitas dan dialogis.

\section{METODE PENELITIAN}

\section{Seting Penelitian}

Penelitian ini berbentuk Penelitian Tindakan Sekolah (PTS). Penelitian ini dilaksanakan di TK Al Isro' Kota Jambi. Subyek dan obyek penelitian

\footnotetext{
${ }^{6}$ Bahan pembelajaran supervisi akademik", noreg: BA06/P2CKS/5/I/2011, oleh Lembaga
} pengembangan dan pemberdayaan kepala sekolah Surakarta 2011. 
adalah guru TK Al Isro' yang beralamatkan di J1. Kapten Pattimura RT 02 Kel Kenali Besar Kec. Alam Barajo kota Jambi.

Waktu penelitian dilaksanakan pada bulan september hingga oktober 2017/2018. Dengan penelitian ini diharapkan para guru TK Al Isro' mengalami perubahan dan peningkatan minimal $100 \%$, dari 5 guru TK mampu merencanakan program harian dengan menentukan langkah-langkah pembelajaran sesuai dengan metode dan teknik kegiatan. Melaksanakan pembelajaran sesuai RKH yang PAIKEM. Melakukan evaluasi hasil belajar yang prosedural.

\section{Prosedur Penelitian}

Prosedur penelitian adalah rangkaian tahapan penelitian dari awal sampai akhir. Penelitian ini merupakan proses pengkajian, seperti yang dikembangkan Supardi Suharjono, 2013 dalam Strategi menyusun penelitian tindakan kelas. Prosedur ini mencakup tahapan-tahapan, yaitu:
a. Perencanaan,
b. Pelaksanaan,
c. Pengamatan, dan
d. Refleksi.

\section{Analisis Data}

Analisis data yang digunakan dalam penelitian ini adalah: (1) Analisis Diskriptif Komparatif; (2) Analisis Deskriptif Prosentase.

\section{Indikator Keberhasilan}

Indikator Keberhasilan yang penulis tentukan setelah guru Taman Kanakkanak selama dilakukan tindakan I dan II dari kondisi awal sampai dengan akhir kegiatan siklus I dan siklus II berakhir diperoleh peningkatan mencapai $100 \%$, dari 5 guru TK Al Isro’ Kota Jambi, dengan kategori baik dan dengan skor 71-85. 


\section{HASIL PENELITIAN DAN PEMBAHASAN}

\section{Hasil Penelitian}

\section{1) Hasil Pra Penelitian/ Pra Siklus}

a. Dari observasi diketahui bahwa dari lima guru TK dalam menyusun Rencana Kegiatan harian, kemampuan melaksanakan pembelajaran, dan kemampuan mengevaluasi hasil belajar siswa dengan skor rata-rata 57,33. Hal ini berarti bahwa kinerja mengajar guru TK Al Isro' sebagian besar berada pada kategori Sedang.

b. Hasil penilaian kemampuan guru dalam merencanakan pembelajaran, melaksanakan pembelajaran, dan kemampuan guru dalam mengevaluasi hasil belajar siswa dari Kepala TK melalui Angket.

Berdasarkan hasil observasi, menunjukkan bahwa Kinerja mengajar guru TK Al Isro' pada aspek perencanaan pembelajaran diperoleh skor terendah 55,00, skor tertinggi 60,00, skor rata-rata 57,00, dan ketuntasan klasikal 0\%, dengan kategori Sedang. Pada aspek pelaksanaan pembelajaran diperoleh skor terendah 60,00, skor tertinggi 62,66, dan skor rata-rata 61,05, dengan kategori Sedang, ketuntasan klasikal $0 \%$.

Sedangkan aspek kemampuan dalam mengevaluasi hasil belajar siswa diperoleh skor terendah 51,11, skor tertinggi 63,33, skor rata-rata 56,93, dengan kategori C, ketuntasan klasikal 0\%.

\section{2) Hasil Siklus I (Satu)}

Hasil Observasi Kinerja mengajar guru TK Al Isro' dilakukan pada tanggal 5 September 2017, dapat diketahui bahwa Kinerja mengajar guru TK Al Isro' pada aspek perencanaan pembelajaran diperoleh skor terendah 62,50, skor tertinggi 63,75 skor rata-rata 64,25, dan ketuntasan klasikal 0\%, dengan kategori Sedang. Pada aspek pelaksanaan pembelajaran diperoleh skor terendah 57,00, skor tertinggi 62,76, dan skor rata-rata 60,56 dengan kategori Sedang, ketuntasan klasikal 0\%. Sedangkan aspek kemampuan dalam mengevaluasi hasil belajar siswa diperoleh skor terendah 51,11, skor tertinggi 63,33, skor rata-rata 56,93, dengan kategori C, ketuntasan klasikal 0\%. Oleh karena itu masih diperlukan untuk tindakan yang kedua. 
Berdasarkan hasil observasi, menunjukkan bahwa kinerja mengajar guru TK Al Isro' pada siklus I pada aspek Kemampuan dalam merencanakan pembelajaran diperoleh skor 63,25, dengan kategori Sedang dan ketuntasan klasikal pencapaian target indikator keberhasil 0\%. Aspek kemampuan melaksanakan pembelajaran diperoleh skor 61,35, dengan kategori C atau Sedang, dan ketuntasan klasikal pen capaian target indikator keberhasilan 0\%.

Sedangkan pada aspek kemampuan dalam mengevaluasil belajar siswa diperoleh skor 56,95, dengan kategori C atau Sedang, dan ketuntasan klasikal 0\%. Secara umum kinerja mengajar guru kelompok B di gugus Dewi Sartika baru mencapai skor 60,51 dengan kategori $\mathrm{C}$ atau Sedang dan ketuntasan klasikal 0\%. Sehingga masih diperlukan tindakan siklus II.

\section{3) Hasil Penelitian Siklus II (Dua)}

Hasil pengamatan aktivitas kinerja mengajar guru dalam pembelajaran oleh Observer sebagai berikut: kinerja mengajar Guru TK Al Isro' mengalami peningkatan dan perubahan pada aspek kemampuan menyusun perencanaan pembelajaran atau RKH, dengan skor terendah 76,25, skor tertinggi 83,75, dan skor rata-rata 81,75 dengan kategori Baik, dan ketuntasan klasikal pencapaian target indikator keberhasilan $100 \%$.

Pada aspek kemampuan guru dalam pelaksanaan pembelajaran diperoleh skor terendah 74,53, skor tertinggi 78,66, skor rata-rata 75,19 dengan kategori Baik dan ketuntasan klasikal dalam pencapaian target indikator keberhasilan $100 \%$. Pada aspek kemampuan guru dalam mengevaluasi hasil belajar siswa memperoleh skor terendah 74,53, skor tertinggi 78,66, skor rata-rata 75,19, dengan kategori Baik dan ketuntasan klasikal pencapaian target indikator keberhasilan $100 \%$.

\section{Pembahasan Hasil Penelitian}

Kondisi awal kinerja mengajar guru TK pada aspek kemampuan menyusun Rencana Kegiatan Harian secara umum masih dibawah standar dengan skor rata-rata 57,00 atau C, dengan kategori Sedang, hal ini disebabkan dalam perencanaan harian maupun mingguan yang dimiliki oleh guru-guru TK Al Isro' Kota Jambi adalah (1) Pada Recana Mingguan dalam menentukan metode dan 
kegiatan belajar mengajar tidak sesuai antara indikator/ hasil belajar dengan tema yang saat itu sedang berlaku, (2) Dalam Rencana Kegiatan Harian sebagian besar guru-guru belum mencantumkan alokasi waktu pada setiap kegiatan, misalnya kegiatan awal, kegiatan inti, istirahat, dan penutup, (3) Dalam Rencana Kegiatan harian guru-guru belum mencantumkan langkah-langkah pembelajaran yang sesuai dengan metode, (4) Semua guru belum melampirkan alat penilaian yang akan digunakan dalam evaluasi hasil belajar pada RKH.

Setelah dilakukan pembinaan pada pertemuan pertama secara klasikal pada siklus I sebelum pelaksanaan supervisi akademik dilakukan, kondisi kinerja mengajar pada aspek kemampuan guru dalam perencanaan pembelajaran mengalami peningkatan $6,25 \%$ dengan skor rata-rata dari 57,00 menjadi 63,25. Tetapi ketuntasan klasikal dalam pencapaian target masih 0\%. Hal ini disebabkan perencanaan kegiatan harian untuk pembelajaran pada siklus I, dari lima orang guru TK belum mencantumkan langkah-langkah pembelajaran, alat peraga, sumber dan media pembelajran, alat penilaian.

Berdasarkan analisis hasil supervisi akademik melalui observasi pada siklus I, peneliti melakukan program tindak lanjut secara individu pada pertemuan akhir, dan program tindak lanjut secara klasikal pada pertemuan ketiga pada siklus I, dengan melakukan pembinaan, pembimbingan, dan pemberian contoh tentang Rencana Kegiatan Harian model kelompok, area, dan sentra.

Kondisi setelah dilakukan pembinaan, pembimbingan, secara individu dan klasikal dalam program tindak lanjut supervisi akademik pada siklus I pertemuan ketiga, aktivitas guru-guru TK tambah semangat, dan antosias, serta percaya diri, sehingga kinerja mengajar guru pada aspek kemampuan dalam merencanakan kegiatan belajar mengajar pada siklus II mengalami peningkatan yang signifikan. Dari lima orang guru TK Al Isro' kota Jambi diperoleh skor terendah dari 55,0061,87 menjadi 75,00. Skor tertinggi dari 60 ke 63,75, menjadi 81,25. Skor ratarata dari 57,00 ke 63,25 menjadi 79,50. Kategori C Menjadi B, dan ketuntasan klasikal pencapaian target indikator keberhasilan dari $0 \%$ menjadi $100 \%$. 


\section{E. KESIMPULAN DAN SARAN}

\section{Kesimpulan}

Berdasarkan rumusan masalah yang berhubungan dengan peningkatan kinerja mengajar pada aspek kemampuan merencanakan kegiatan pembelajaran, kemampuan melaksanakan pembelajaran, dan kemampuan dalam mengevaluasi hasil belajar siswa dapat disimpulkan:

a. Terdapat peningkatan dan perubahan aspek kemampuan aktivitas guru dalam merencanakan kegiatan pembelajaran guru-guru TK Al Isro’ kota Jambi. Hal ini dapat dilihat dengan adanya peningkatan dari prosentase ketuntasan klasikal pencapaian target indikator keberhasilan yang telah dicapai dari pra siklus $0 \%$ menjdi $100 \%$ pada akhir kegiatan siklus II, peningkatan skor perencanaan pembelajaran pada pra siklus 57,00, menjadi 79,50 setelah akhir kegiatan siklus II, dan adanya peningkatan kategori dari C atau Sedang pada pra siklus menjadi B atau Baik pada akhir siklus II.

b. Aspek aktivitas dan kemampuan guru dalam melaksanakan kegiatan Pembelajaran di TK Al Isro' setelah dilakukan supervisi akademik dengan teknik observasi kelas mengalami peningkatan dan perubahan secara signifikan. Peningkatan tersebut dapat dilihat dari perolehan skor dari prasiklus, siklus I, dan siklus II. Skor pada pra siklus diperoleh 61,05, pada siklus I meningkat menjadi 61,35, dan siklus II meningkat menjadi 76,36, dengan peningkatan total dari pra siklus hingga siklus II 15, 31\%. Peningkatan pada ketuntasan klasikal pencapaian target indikator keberhasilan sangat signifikan, karena dari pra siklus hingga siklus II mengalami peningkatan dari 0\% menjadi $100 \%$. Sedangkan untuk kategori dari C atau Sedang menjadi B atau Baik.

c. Bahwa aspek akivitas dan kemampuan mengevaluasi hasil belajar siswa bagi guru-guru TK Al Isro' mengalami peningkatan dan perubahan setelah dilakukan supervisi akademik dengan teknik observasi kelas dari siklus I hingga siklus II. Peningkatan yang terjada adalah dalam hal pemanfatan alat atau intrumen penilaian, dan prosedur penilaian. Peningkatan dapat dilihat dari hasil pengamatan dan penilaian peneliti dan observer dengan skor pada pra 
siklus 56,93 menjadi 56,95 pada siklus I, dan meningkat menjadi 75, 56 pada siklus II. Ketuntasan klasikal pencapaian target indikator keberhasilan pada pra siklus $0 \%$, siklus I 0\%, siklus II meningkat secara signifikan dari lima orang guru TK diperoleh skor terendah 72, 44, dan skor tertinggi 78,66, berarti mengalami peningkatan $100 \%$. Peningkatan juga terjadi pada kategori dari pra siklus C, siklus C, menjadi B pada siklus II.

\section{Saran}

Berdasarkan hasil Penelitian Tindakan Sekolah yang sudah dilakukan oleh peneliti memberikan saran sebagai berikut:

\section{Bagi Guru}

Untuk selalu berupaya meningkatkan kinerja mengajarnya melalui kegiatan gugus, dalam perencanaan pembelajaran, pelaksanaan pembelajaran,dan peningkat-an dalam mengevaluasi hasil belajar siswa dengan pemanfaatan alat penilaian secara maksimal.

2. Bagi Kepala TK

Sebagai bahan pertimbangan untuk melakukan pembinaan dan bimbingan terhadap guru-guru dalam rangka peningkatan kinerja mengajarnya.

\section{DAFTAR PUSTAKA}

Anwar Prabu Mangkunegara, Manajemen Sumber Daya Manusia Perusahaan. Bandung: PT. Remaja Rosdakarya, 2007.

Supardi, Kinerja Guru, Jakarta: Grafindo, 2014.

Permendiknas Nomor 41 Tahun 2007 tentang Standar Proses untuk Satuan Pendidikan Dasar dan Menengah. Departemen Pendidikan Nasional, Jakarta, 2007.

Undang-undang Republik Indonesia Nomor 14 Tahun 2005 tentang Guru dan Dosen.

Ambar Teguh Sulistiyani dan Rosidah. 2003. Manajemen Sumber Daya Manusia: Konsep, Teori dan Pengembangan dalam Konteks Organisasi Publik. Yogyakarta: Graha Ilmu, 2003.

Nurlaila, Manajemen Sumber Daya Manusia, Jakarta: Penerbit LepKhair, 2010.

F. Luthans, Organizational Behavior. New York: McGraw-hill, 2005. 
Veithzal Rivai dan Basri. Peformance Appraisal: Sistem yang tepat untuk Menilai Kinerja Karyawan dan Meningkatkan Daya Saing Perusahan. Jakarta: PT. RajaGrafindo Persada, 2005.

R.L. Mathis \& J.H. Jackson. Human Resource Management: Manajemen Sumber Daya Manusia. Terjemahan Dian Angelia. Jakarta: Salemba Empat, 2006.

AA. Anwar Prabu Mangkunegara, Manajemen Sumber Daya Manusia Perusahaan, (Bandung: Remaja Rosdakarya, 2008.

E. Mulyasa. Standar Kompetensi dan Sertifikasi Guru. Bandung: Remaja Rosdakarya, 2007.

Mohamad Surya. Psikologi Pembelajaran dan Pengajaran. Bandung: Pustaka Bany Quraisy, 2004.

Nana Sudjana, Dasar-Dasar Proses Belajar Mengajar. Bandung: Sinar Baru Offset, 1987.

Jasmani Asf, Supervisi Pendidikan (terobosan baru dalam peningkatan kinerja pengawas sekolah dan guru), Jogjakarta: Ar-ruzz Media, 2013.

Iskandar, Urai, Macam-macam supervisi. https://uray-iskandar.blogspot.com

Bahan pembelajaran supervisi akademik”, noreg: BA06/P2CKS/5/I/2011, oleh Lembaga pengembangan dan pemberdayaan kepala sekolah Surakarta 2011. 